\title{
AGAMA DALAM PRAKTIS BUDAYA (SUATU TINJAUAN SOSIOLOGI AGAMA)
}

Ni Nyoman Dewi Astari Putri ${ }^{1}$

\section{Abstract}

Keywords
From the perspective of religion and culture, the phenomena found in the society especially humans' life are closely related to one another. This phenomenon is sometimes misunderstood by some people who do not understand how to place religious and cultural positions in people's lives. In human life, religion and culture do not stand alone or stand by themselves, both have a very close relationship in their dialectics; aligned to create and then negate each other. Religion is a guideline for human life that is used as a reference in living their life, while culture is a habit or way of human life that is created by humans themselves from the results of creativity, feeling, and intention given by God. Religion and culture influence each other. Religion affects the culture, community groups, and ethnic groups. However, culture tends to be fickle. This relationship has implications for the authenticity of religion, resulting in different interpretations. Religion is an idea that is idolized in every social action so that society is always in balance and order of a stable system and structure. This condition can be expected to give rise to a serene and peaceful social life in which the function of religion becomes important and dominant. In this way, religion in turn truly places itself as a regulator of the traffic of social obligations through its commands and prohibitions, and in it, society cannot refuse it. The point is that in recent times, since the 20th century, religion has become an attractive object for scientists and culture.

\section{PENDAHULUAN}

Konflik agama mungkin bukan bahasan yang asing lagi dalam masyarakat, karena memang konflik agama menjadi permasalahan yang sampai sekarang masih belum dapat diselesaikan dengan baik. Konflik agama bukan hanya menjadi permasalahan di Indonesia saja tetapi juga di seluruh dunia. Ini disebabkan karena Indonesia memiliki bermacam-macam etnis dan agama. Agama secara normatif terlalu jauh dari hasrat untuk melakukan penekanan-penekanan, baik inter maupun

\footnotetext{
${ }^{1}$ dewiastariputri22@gmail.com
} 
antarumat beragama. Karena selain mengutamakan religi, agama juga mengajarkan etiket dan menganjurkan moralitas. Ini menunjukkan bahwa agama adalah sumber nilai dan norma moral penting dalam berbagai praktik kehidupan manusia. Oleh karena itu, di Indonesia kebebasan dalam beragama sungguh dijamin undang-undang, bahkan umat beragama diberikan kebebasan dalam menjalankan berbagai praktik agama. Tetapi fenomena keberagaman belakangan ini menunjukkan adanya kecenderungan semakin menajamnya persoalan-persoalan keagamaan, khususnya menyangkut tekanan-tekanan yang dialami oleh agamaagama tradisional dari kelompok agama mainstream. Padahal agama tradisional telah terbukti memainkan peranan penting bagi kehidupan manusia sejak berabad-abad silam. Agama tradisional telah dijadikan pedoman tingkah laku dalam mewujudkan kesadaran kolektif masyarakat. Karena agama tradisional pula, keteraturan, kesimbangan sistem dan struktur masyarakat dapat dipertahankan. Kasuskasus mengenai konflik agama diatas merupakan salah satu contoh kasus yang pernah dipublikasikan oleh media. Konflik agama memang sudah menjadi realita sosial di masyarakat kita yang sampai sekarang belum dapat diselesaikan secara baik. Sudah tentu media massa harus menjadi mediator dalam pensosialisasian hal-hal yang berkaitan dengan adanya kerusuhankerusuhan yang diakibatkan oleh konflik agama tersebut.

Pertanyaannya, mengapakah terjadi hal seperti ini di negeri yang konon sangat religius? Apakah sebenarnya fungsi agama dalam praktis budaya? Permasalahan tersebut akan menjadi topik pembahasan dalam tulisan dengan pendekatan sosiologis.
Dalam pendekatan ini diasumsikan bahwa agama selalu dikontekstualisasikan oleh penganutnya dengan kebudayaan dalam berbagai praktik sosial. Dengan demikian agama diposisikan dalam kedudukannya sebagai agama masyarakat.

\section{PEMBAHASAN}

\section{Agama dan Persoalan Kemanusiaan}

Agama adalah keyakinan yang bersumber pada ajaran-ajaran suci yang diwahyukan Tuhan untuk memberikan tuntunan bagi manusia dalam menjalani kehidupan di dunia sehingga mampu mencapai kebahagiaan jasmani/duniawi dan kebahagiaan rohani/surgawi. Tujuan hidup tersebut menjadi penting untuk diketahui dan dipahami secaar seksama sebab ia akan menjadi landasan utama umat manusia dalam berbagai aktivitasnya. Mengapakah harus berangkat dari landasan agama? Agama dalam bentuk apapun selalu muncul sebagai kebutuhan ideal umat manusia.

Oleh karena itu peranan agama sangat menentukan dalam setiap kehidupan. Tanpa agama manusia tidak akan hidup sempurna. Peranan agama menjadi sangat penting dalam kehidupan manusia karena agama terkait dengan kebudayaan di masyarakat. Sehingga agama dan masyarakat saling mempengaruhi (Utama, 2006: 2). Ini berarti ide tentang kesempurnaan hidupa sangat tergantung kepada agama karena ajarannya yang diwahyukan oleh Tuhan haruslah dipercaya sedemikian rupa. Kebenaran agama adalah kebenaran wahyu, maka di dalamnya terdapat kepercayaan (religious).

Agama berisi ajaran-ajaran tentang kebenaran tertinggi dan mutlak tentang eksistensi manusia dan petunjuk-petunjuk untuk hidup selamat di dunia dan di akhirat (setelah mati). Agama Sebagai sistem keyakinan dapat menjadi bagian dari sistem 
nilai yang ada dalam kebudayaan masyarakat bersangkutan. Agama menjadi pendorong, penggerak, serta pengontrol tindakan-tindakan para anggota masyarakat untuk tetap berjalan sesuai dengan nilai-nilai kebudayaan dan ajaran-ajaran agamanya. Dalam hal ini agama sebagai sumber normal tidaklah mungkin mengandung kesalahankesalahan ataupun keburukan-keburukan yang dapat menyebabkan manusia (penganutnya) bertindak kea rah yang kontra produktif terhadap kesempurnaan hidup. Dengannya agama menjadi pedoman bagi seluruh nilai kesempurnaan hidup yang layak diperebutkan dan diperjuangkan dalam segala lini kehidupan karena hanya dengan demikian agama benar-benar menjadi milik sebuah masyarakat. Ini sebabnya agama benar-benar hidup di setiap hati masyarakat sebagai pembakar semangat sosial dan pewarna bagi keindahan kebudayaan suatu masyarakat yang layak disebut sebagai masyarakat beradab.

Akan tetapi ketika agama mengaktualisasi diri dalam kehidupan para pemeluknya, maka keberagamaan terintegrasi ke dalam sistem nilai sosial budaya, dan wujud kebudayaan fisik yang kemudian bersentuhan melalui proses sosial dengan elemen-elemen sosial budaya lainnya. Secara sosiologis agama dalam realitas kehidupan akan bersentuhan pula dengan pemenuhan kebutuhan hidup manusia, baik yang bersifat fisik-biologis, sosial, ekonomi, dan politik, maupun kebutuhan-kebutuhan intergratif yang menyangkut hal-hal yang sangat penting dalam kehidupan manusia, yaitu keinginan untuk hidup beradab, bermoral, tenteram, dan damai.

Dengan demikian dapat dikatakan bahwa keberagaman itu saling terkait antara hal-hal yang bersifat normatif dengan dimensi kehidupan yang bersifat praksis aktual, baik pada level individual maupun kolektif. Agama pada titik ini memiliki posisi sentral terutama berkaitan dengan pembentukan nilai-nilai dan norma-norma sosial yang dalam praktiknya tidak jarang ditemukan saling berbenturan antara yang satu dengan yang lain. Agama diharapkan mampu menjadi pendamai dalam paradoksal kehidupan nilai dan norma dalam tataran yang paling sublime. Karena selain agama manusia tidak lagi memiliki keyakinan tempat menyandarkan nilai kehidupan yang terakhir.

Keberagaman bukanlah keterpisahan secara total antara sistem gagasan dan praktiknya dalam dunia empiris berupa pengalaman-pengalaman. Melainkan keduanya merupakan kesatuan ide dan praktik dalam bentuk pengabdian diri secara terus-menerus. Hal itu akan mengantarkan penganutnya kepada ketenangan dan kedamaian hati. Fenomena keagamaan menyangkut tindakan keagamaan dalma konteks sosial budaya. Malahan agama memperoleh arti dan maknanya yang tertinggi justru dalam praktiknya, bukan hanya dalam pikiran karena berpikir tidak pernah eksis di dalam tradisi.

Dalam agama sistem tindakan mendapat nilai yang seluas-luasnya karena beragama berarti bertindak menurut agama dna bukan hanya berpikir dan berkata-kata menurut agama, apalagi tentang agama. Dalam hal ini tidak dapat dihindari bahwa agama fungsional dalam sistem dan struktur berpikir dan bertindak manusia yang senantiasa menjaga integritas kepribadian penganutnya. Jadi, agama merupakan faktor yang menentukan sistem dan struktur tindakan sosial dan kebudayaan dalam berbagai lapangan kehidupan manusia 
sehingga agama diharapkan mampu memecahkan persoalan hidup manusia dan kemanusiaan.

\section{Agama dan Fungsinya Dalam Kehidupan Umat Manusia}

Agama berkaitan dengan usaha manusia untuk mengukur dalamnya makna dari keberadaanya sendiri dan keberadaan alam semesta. Selain itu, agama juga dapat membangkitkan kebahagiaan bathin yang paling sempurna dan juga perasaan takut. Meskipun perhatian ditujukan kepada adanya suatu dunia yang tidak dapat dilihat (akhirat), namun agama melibatkan dirinya dalam masalah-masalah kehidupan seharihari di dunia. Agama seringakali bersifat paradox, di satu sisi agama dijalani sebagai jalan penjamin menuju keselamatan, cinta, dan perdamaian, sementara itu, di sisi lain agama justru menjadi sumber penyebab dan alasan bagi kehancuran dan kemalangan umat manusia.

Mungkin, ungkapan yang menyatakan bahwa manusia akan hidup lebih baik, tertib dan bahagia jikalau hidupnya tanpa agama, seolah-olah benar adanya. Oleh karena agama orang bisa saling mencintai, tetapi atas nama agama pula orang bisa saling membunuh dan menghancurkan (Sindhunata, 2003:13). Sampai di sini agama seperti pisau bermata dua terhadap eksistensi manusia. Agama menyebabkan kebahagiaan dan agama juga menyebabkan kesengsaraan, atau agama yang menyebabkan dan menciptakan kedamaian dan kelestarian, tetapi agama juga yang menyebabkan peperangan dan kehancuran. Oleh karena itu seolah-olah agama memiliki kepribadian ganda (double personality), yang satu lembur dan melankolis, sedangkan yang lain kasar dan keras.
Berkaitan dengan kepribadian yang kedua, agama sebagai yang bersifat kasar dan keras, beberapa catatan sejarah menunjukkan bahwa agama telah menjadi pemicu permusuhan di beberapa tempat. Tetapi harus pula diakui bahwa agama telah berhasil memberikan nilai dan arti bagi kehidupan umat manusia. Apabila demikian keadaannya dapatkah agama diharapkan membantu manusia dalam mengatasi berbagai problem kehidupannya? Jawaban atas pertanyaan ini sesungguhnya kembali kepada keinginan manusia itu sendiri, apakah manusia akan membiarkan terjadinya pembusukan terhadap agama ataukah mereka akan mengembalikan agama pada fungsinya. Dalam hal ini agama adalah 'instrumen' bagi manusia untuk mewujudkan keinginannya, tetapi keinginan manusia selalu berubah-berubah sehingga agama juga mengalami perubahan sesuai dengan keinginan manusia. Jadi, agama sesungguhnya tidak pernah mencapai perkembangannya yang final sehingga agama seolah-olah tidak memiliki tujuan yang pasti. Dalam hal ini manusia bersikap munafik terhadap agama-nya, sehingga terjadi pembusukan dna pertukaran peran secara silih berganti sepanjang waktu, yakni pada saat tertentu manusia membutuhkan agama, sedangkan pada saat lain agama memerlukan manusia.

Menurut Kimball (seperti dikutip Sindhunata, 2003) ada lima tanda yang bisa membuat agama busuk dan korupmenyimpang dari fungsinya. Pertama, apabila suatu agama mengklaim kebenaran agamanya sebagai kebenaran yang mutlak dan satu-satunya. Kedua, adalah ketaatan buta kepada pemimpin keagamaan mereka. Ketiga, apabila agama mulai cenderung merindukan zaman ideal, lalu bertekad merealisasikannya pada zaman sekarang. 
Keempat', apabila agama tersebut membenarkan dan membiarkan terjadinya 'tujuan yang membenarkan cara'. Kelima, apabila agama tidak segan-segan memekikkan perang suci.

Walaupun demikian, cukup satu saja di antara kelima penyabab pembusukan agama itu ada di dalam masyarakat penganut suatu agama. Kalau kelimalimanya ada dalam diri penganut agama, maka kiamatlah kehidupan sosial suatu masyarakat. Sebab kelima klaim pembusukan agama itu merupakan simbol kehancuran tatanan nilai-nilai kemanusiaan itu sendiri.

Misalnya, dengan mengatakan bahwa "agama saya adalah agama yang mutlak benar dan satu-satunya", dengan kata lain saya hendak mengatakan bahwa "agama orang lain sama sekali tidak memiliki kebenaran, atau agama orang lain adalah agama yang salah". Dapat dibayangkan betapa seorang penganut agama telah menutup kemungkinan-kemungkinan lain yang akan memberikan kebenaran tentang kebenaran-kebenaran yang telah dengan sengaja ditolak sebelum kebenaran itu datang. Menutup diri dari kemungkinan memperoleh kebenaran itu datang. Menutup diri dari kemungkinan memperoleh kebenaran yang lain merupakan sikap pembodohan (pembusukan) dari dalam. Sebaliknya, dapat dibayangkan berbagai kemungkinan yang buruk (busuknya) reaksi dari lingkungan eksternal, yaitu dari para penganut agama yang lain, dari berbagai perspektif agama yang lain. Ini merupakan model kehancuran kebenaran agama paling dasyat yang mungkin dibayangkan.

Paparan itu kiranya bisa menyadarkan umat beragama, baik secara institusional maupun individu untuk bercermin ke arah penghayatan keagamaannya sedang bergerak. Apabila indikasi-indikais tersebut telah semakin menonjol dalam kalangan umat beragama, bisa diasumsikan bahwa institusi keagamaan telah gagal dalam perannya sebagai mediator dalam menyampaikan ajaran-ajaran kesucian agama kepada para pemeluknya. Indikasiindikasi di atas secara jelas telah menunjukkan bahwa hal itu sangat bertentangan dengan fungsi agama yang sesungguhnya dalam masyarakat.

Dikatakan demikian karena manusia dan masyarakat pada hakikatnya mempunyai kebutuhan-kebutuhan tertentu demi kelangsungan hidup dan pemeliharaannya sampai batas minimal. Sementara itu, agama berfungsi memenuhi sebagian di antara kebutuhan-kebutuhan itu, meskipun kadang-kadang terdapat ketidakcocokan dalam cara memenuhi kebutuhan tersebut. Agama diyakini mampu mengakomodasi kepentingan-kepentingan manusia berdasarkan pertimbanganpertimbangan berikut.

Pertama, agama telah membantu mendorong terciptanya persetujuan mengenai sifat dan isi kewajiban-kewajiban sosial dengan memberikan nilai-nilai yang berfungsi menyalurkan sikap-sikap anggota masyarakat dan menetapkan isi dari kewajiban-kewajiban sosial mereka. Dalam hal ini, agama telah membantu menciptakan sistem-sistem nilai sosial yang terpadu dan utuh. Sangatlah sulit bagi manusia, dalam jangka waktu yang cukup lama, tetap bersepakat mengatur tingkah laku mereka sesuai dengan bermacam-macam larangan dan perintah yang satu sama lainnya tidak bertalian.

Banyak krisis disiplin dalam masyarakat, seperti disiplin sekolah, lalu lintas cenderung menjadi gagal ketika 
penegakan disiplin itu semata-mata ditekankan dengan menggunakan kekuatan fisik. Di samping itu banyak contoh telah menunjukkan bahwa masyarakat tidak dapat dipertahankan keutuhannya dalam jangka waktu yang panjang jika hanya menggunakan kekuatan fisik. Dari dimensi ini, kemampuan menghargai norma dan nilai sosial budaya merupakan hal penting yang mutlak dilakukan kepada umat beragama.

Apabila masyarakat diharapkan tetap stabil dan tingkah laku sosial masyarakat bisa tertib dan baik maka tingkah laku yang baik harus ditata dan dipolakan sesuai prinsipprinsip tertentu yang relatif diterima dan disepakati bersama. Prinsip-prinsip dasar tersebut berkaitan dengan tujuan-tujuan atau sasaran utama tingkah laku sosial manusia. Tujuan-tujuan semacam itu disebut dengan nilai-nilai. Pada saat nilainilai suatu masyarakat dapat diintegrasikan dalam tatanan atau sistem, berarti pada saat itulah anggota masyarakat dapat bersatu menuju ke satu arah dalam tingkah laku mereka, dan hal ini mungkin tidak akan pernah terwujud dengan sempurna. Nilainilai yang dipegang dan dipedomani dalam suatu masyarakat biasanya berjenjang dan berstruktur. Dalam hirarki ini agama menduduki jenjang yang tertinggi meskipun seringkali tidak disadari oleh masyarakat. Dengan demikian dapat dikatakan bahwa agama dalam hal ini adalah sebagai pengintegrasian nilai-nilai yang dipegang oleh suatu masyarakat.

Kedua, agama juga memainkan pernana penting dalam memberikan kekuatan memaksa sehingga mendukung dan memperkuat adat istiadat. Sikap mengagungkan dan rasa hormat terutama yang berkaitan dengan adat istiadat (sistem moral) yang berlaku. Itu berhubungan erat dengan perasaan-perasaan kagum yang ditimbulkan oleh yang sakral itu sendiri (Nottingham, 1992: 36). Sebagaimana dimaklumi bahwa masyarakat Hindu Bali dikenal memiliki dan menjunjung tinggi adat istiadatnya.

Mungkin sering kali muncul pertanyaan apa yang menyebabkan adat istiadat itu memilki kekuatan memaksa sehingga orang mau melaksanakannya? Ada satu hal yang menjadi kunci jawaban dari pertanyaan itu adalah adanya nilai-nilai agama yang memberi rog bagi pelaksanaan adat istiadat itu. Dengan adanya normanorma agama memungkinkan disesuaikannya tingkah laku manusia dengan norma-norma tersebut. Namun penyesuaian dengan norma-norma tersebut akan lebih memiliki kekuatan memaksa, apabila hal itu disertai dengan ganjaran-ganjaran.

Ganjaran dan hukum sosial (sanksi sosial) tersebut sampai taraf tertentu masih diakui dalam semua norma sosial. Hanya saja kebanyakan orang mau menyesuaikan diri dengan norma-norma itu karena pernah menerima sanksi atau cemohan dari temantemannya. Jika norma-norma tersebut dikaitkan dalam kerangka yang sakral maka sanksinya pun dikaitkan dengan hal-hal yang bersifat sakral. Dengan demikian dapat dikatakan bahwa agama telah memberikan dasar yang kuat bagi penetapan normanorma sosial dalam masyarakat sehingga norma-norma sosial itu mempunyai kekuatan memaksa untuk menata perilaku masyarakat. Dengan menempatkan agama sebagai norma tertinggi pola rujukan tingkah laku, ganjaran yang diterima pun tidak hanya bersifat duniawi, tetapi juga dunia yang lain, selain dunia nyata ini.

Ini berarti peranan agama dalam masyarakat harus dilihat terutama sebagai sesuatu yang mempersatukan, baik dalam pemikiran maupun tindakan. Dengan kata 
lain agama telah menciptakan ikatan bersama termasuk dalam kewajibankewajiban sosial yang membantu mempersatukan mereka. Agama berfungsi sebagai pelestarian nilai-nilai yang sacral sehingga memungkinkan nilai-nilai tersebut dapat ajeg terhadap perubahan-perubahan yang selalu terjadi pada masyarakat pendukungnya. Dalam hal ini agama dimanfaatkan untuk mewadahi norma dan nilai yang menata system dan struktur sosial dalam suatu masyarakat.

Agama menjadi ide yang diidolakan pada setiap tindakan sosial sehingga masyarakat senantiasa berada dalam keseimbangan dan keteraturan system dan struktur yang mantap. Kondisi ini dapat diharapkan memunculkan kehidupan sosial yang tenteram, damai yang didalamnya fungsi agama menjadi penting dan dominan. Dengan begitu agama pada gilirannya sungguh-sungguh menempatkan dirinya sebagai pengatur lalu lintas kewajibankewajiban sosial melalui perintah dan larangannya dan didalamnya masyarakat tidak dapat menolaknya. Inti sebabnya pada waktu belakangan ini sejak abad ke -20 agama menjadi objek menarik bagi kalangan ilmuan dan kebuadayaan.

Salah satu gejala intelektual yang paling menarik pada abad ke-20 adalah besarnya minat untuk mempelajari agama, dan pada suatu ketika terdapat kesesuaian pendapat secara luas bahwa kepercayaan agama sebagaimana dipahami secara tradisional, sangat mencolok makna intrinsiknya bagi sebagian besar warga masyarakat modern. Memperhatikan perkembangan studi agama-agama dewasa ini dapat dikelompokkan menjadi dua pendekatan. Pendekatan yang pertama bersifat teophosentris, yaitu menelaah agama sebagai seperangkat ajaran-ajaran dari Tuhan yang tercantum dalam kitab-kitab suci.

Agama dipandang sebagai seperangkat keyakinan yang sacral dan mutlak, yang mengatur hubungan manusia dengan Tuhan, manusia dengan sesamanya, dan manusia dengan alam dan lingkungan dimana ia berada. Studi agama seperti ini bersifat normative atau dengan kata lain menggunakan pendekatan yang bersifat tekstual. Pada dimensi ini agama diletakkan sebagai standar acuan sopan santun tingkah laku sosial budaya. Agama dipandang sebagai pusat-pusat orientasi nilai yang memiliki kebenaran analitis-ideologis.

Pendekatan kedua, agama ditelaah sebagai kenyataan yang bersifat sosiohistoris yang tumbuh dan berkembang dalam pengalaman perilaku para pemeluknya. Dalam pendekatan ini agama lebih dimaknai dalam konteks kehidupan dan kebudayaan para pemeluknya. Pendekatan ini lebih bersifat kontekstualempirik. Di dalam praktik ini kebenaran agama secara tekstual mendapatkan nilai tertingginya karena kebenaran agama lebih ditekankan pada praktiknya, bukan hanya dalam kebenaran normatifnya. Walaupun tidak setiap kebenaran secara normative selalu sama dengan kebenaran agama secara praksis dalam kehidupan sosial karena pada kenyataannya tidak ada ide yang eksis dalam realitas empiris. Akan tetapi setidaktidaknya agama memiliki dua dimensi penting bagi manusia, yakni menata pemikiran, sikap manusia dan juga menata tindakannya dalam berbagai aspeknya. Secara tekstual agama menata pemikiran manusia sehingga secara kontekstual ia tidak tersesat dalam dunia pengalaman yang sarat dengan kontrakdisi nilai dan norma. Perpaduan antara agama sebagai kebenaran tekstual dan kontekstual merupakan 
ideologi tertinggi dari sebuah cita-cita keberagamaan dalam setiap kehidupan manusia.

Walaupun demikian, kedua pendekatan ini sepertinya berlawanan arah dengan segala kemungkinan yang akan terjadi kelak karena pada kenyataannya tidak pernah ada kebenaran subjektif sekaligus objektif. Oleh karena itu, bisa jadi muncul dekonstruksi terhadap ajaran-ajaran agama yang selama ini telah dianggap mapan. Namun tidak tertutup kemungkinan akan terjadi proses dialektis yang akan menghasilkan sesuatu yang mengantarkan agama pada situasi yang lebih mendunia tanpa kehilangan maknanya. Proses ini nampaknya sedang berlangsung terus dalam dinamika pemikiran para pemerhati masalah-masalah agama.

Namun demikian harapan yang melekat pada proses itu adalah pertama, agama yang mengandung pesan-pesan moral yang bersifat fundamental dapat digali dan dikembangkan sehingga menjadi nilainilai actual yang memberikan pencerahan bagi kehidupan umat manusia. Dengan demikian studi-studi keagamaan dapat memperkuat sraddha (system keyakinan) umat, bukan sebaliknya, malahan memperlemah keyakinan terhadap sraddha tersebut. Kedua, studi keagamaan juga diharapkan lebih fungsional dalam membantu manusia meghadapi poblemapoblema kehidupan yang semakin sulit saat ini. Mengingat begitu banyaknya persoalan hidup yang muncul dari aspek kehidupan lainnya sehingga diharapkan keagamaan tidak menambah persoalan itu. Ketiga, studistudi agama diharapkan dapat mempersempit jurang fanatisme sempit sehingga memungkinkan terciptanya keharmonisan dalam masyarakat yang multicultural.
Perkembangan terakhir tentang kehidupan beragama di Bali menunjukkan fenomena menarik dari perspektif studistudi keagamaan. Gejala pertama, yaitu semakin gencarnya para tokoh agama untuk menyosialisasikan ajaran agama dalam kehidupan sehari-hari. Maupun dalam halhal yang lebih bersifat fundamental. Simak saja materi-materi yang disampaikan oleh Ida Pedanda Made Gunung melalui Dharma Wacana di Bali TV ataupun melalui tulisantulisan agama di media cetak Bali Post.

Kedua, adanya kecendrungan meningkatkan pengalaman ajaran agama melalui kegiatan-kegiatan rirual, serta pendalaman aspek-aspek agama melalui kelompok-kelompok kepentingan khusus, seperti "ngayah sareng-sareng" yang dikoordinir oleh media cetak Nusa dengan kegiatan sosial religious di lingkungan tempat-tempat suci di Bali. Perkembangan positif tersebut paling tidak memberikan indikasi bahwa kekhawatiran akan munculnya sekularisme hedinisme, materialism telah menjadi kekuatan penyeimbang yang berarti sehingga akan terjadi masyarakat equilibrium di Bali.

\section{PENUTUP}

\section{Simpulan}

Dari paparan di atas kiranya dapat dipahami bahwa agama dalam kehidupan manusia sebagai individu berfungsi sebagai suatu system nilai yang memuat normanorma tertentu. Secara umum norma-norma tersebut menjadi kerangka acuan dalam bersikap dan bertingkah laku agar sejalan dengan keyakinan agama yang dianutnya. Nilai adalah daya pendorong dalam hidup, yang memberi makna dan pengabsahan pada tindakan seseorang. Oleh karena itu nilai menjadi penting dalam kehidupan seseorang sehingga tidak jarang pada tingkat 
tertentu orang siap untuk mengorbankan hidupnya demi mempertahankan nilai-nilai yang mereka pegang dan yakini benar.

Bom bunuh diri misalnya, merupakan kasus nyata mengenai dominannya peran agama dalam membentuk ideology seseorang atau kelompok. Secara empiris apabila seseorang tersentuh ideologinya, maka ia akan sanggup megorbankan segalanya termasuk nyawa demi memperjuangkan ideology tersebut. Hal ini banyak dibuktikan dalam penerapan teori konflik di daerah-daerah rawan perseteruan, seperti di Poso dan Maluku misalnya. Akan tetapi dalam kasus yang lebih sederhana di Bali, terjadinya kasus adat dan agama, perselisihan dalam pembagian warisan dalam sebuah keluarga, dimana nilai warisan yang diperebutkan akhirnya jauh lebih kecil daripada biaya yang dikeluarkan demi memperoleh keadilan-perjuangan ideologi.

Dilihat dari fungsi dan peran agama dalam memberikan pengaruhnya terhadap individu, baik dalam bentuk system nilai, motivasi maupun pedoman hidup maka pengaruh yang paling penting adalah sebagai pembentuk kata hati (Ishomuddin, 2002:36). Agama mempunyai pengaruh dalam mendorong individu untuk melakukan suatu aktivitas karena perbuatan yang dilakukan dengan latar belakang keyakinan agama dinilai mempunyai unsur kesucian serta ketaatan yang tinggi. Dalam hal ini agama dapat berperan sebagai motivator dan inspiratory bagi tindakan seseorang. Sementara agama sebagai nilai etik membimbing manusia untuk bertindak sesuai dengan norma-norma sehingga dapat memilah mana yang boleh dilakukan dan mana yang harus dihindari sesuai ajaran agamanya masing-masing, atau dengan kata lain agama bisa menjadi etos kerja masyarakat pemeluknya, sebab orang yang melaksanakan ajaran agama dengan baik banyak didorong oleh adanya harapan tentang pengampunan atau kasih sayang dari Tuhan/Hyang Widi Wasa. Ajaran-ajaran agama yang berisikan tentang kebahagiaan akhirat di samping kebahagiaan dunia menjadi kekuatan sendiri bagi manusia dalam menghadapi dinamika kehidupan yang tidak selamanya sesuai dengan harapan. Banyak hambatan dan tantangan dapat muncul dalam kehidupan manusia dan ketika pendekatan rasional muncul dalam kehidupan manusia dan ketika pendekatan rasional telah mengalami jalan buntuk maka agama hadir menawarkan harapan.

Ini berarti agama menjadi upaya terakhir bagi perjalanan nalar manusia dalam mencari dan menemukan kebenaran. Pada tingkat ini agama menjadi rujukan tertinggi bagi cita-cita kemanusiaan sebab kekuatan akal dan kemampuan nalar, ternyata tidak selalu memuaskan kebutuhan manusia tentang kebenaran. Pada kenyataannya tidak semua dimensi kehidupan manusia dapat dipahami hanya dengan mengandalkan akal dalam kerangka rasionalitas sebab menurut pandangan psikoanalisis kesadaran manusia ibarat gunung es (Hall, 1980). Kekuatan akal hanya mampu menggapai puncaknya saja sebagai kesadaran konvensional, sedangkan kesadaran alamiah manusia secara potensial tersimpan sebagai ketaksadaran. Boleh jadi, apa yang dimaksudkan oleh Freud sebagai dimensi ketaksadaran (bawah sadar) adalah dimensi religiusitas manusia menurut Eliade, dan oleh Gryson disebut sebagai Kesadaran Universal atau Realitas Tertinggi. Pada dimensi inilah agama memainkan perannya terutama dalam upaya memahami manusia yang multidimensional (Fudyatanto, 2005).

Agama memang berfungsi ganda dan itu sangat tergantung pada para 
penganutnya. Agama dapat berfungsi positif ketika ajarannya dipraktikkan dalam kehidupan sebagai pedoman tingkah laku yang baik dan benar. Dalam hal ini agama menjadi pedoman tingkah laku etis bagi pemeluknya. Sebaliknya, agama akan berfungsi negatif yaitu keluar dari ajarannya ketika penafsirkan ajarannya dilakukan untuk kepentingan kelompok untuk mendominasi kelompok lainnya dalam arti sempit. Ini berarti agama sangat terbuka untuk ditafsir dan dipahami sesuai dengan penganutnya, tempat dimana agama itu dipraktikkan, dan saat agama itu digunakan oleh penganutnya. Agama dalam hal ini akan selalu hidup dalam kontekstualisasinya.

Agama tetap memiliki keterbatasan tergantung pada aktor dibelakangnya dan situasi yang mendukungnya serta tujuan pelakunya. Dalam hal tujuan-tujuan penganutnya, karena itu selalu terjadi adaptasi dan penyesuaian-penyesuaian tujuan sesuai dengan perkembangan tujuan manusia yang selalu berubah-ubah menurut kebutuhannya. Jadi, dalam konteks sosial agama dilaksanakan sesuai dengan kepentingan dan kebutuhan manusia sebagai penganutnya dan bukan selamanya agama dijadikan pedonam tingkah laku.

Agama selalu dinegosiasikan dalam konteks tindakan, ruang dan waktu yang menyertainya. Agama memperoleh nilai dan makna yang tertinggi pada tingkat praksisnya, baik dalam kehidupan sosial maupun budaya dalam masyarakat penganutnya. Demikianlah setiap agama bagi penganutnya merupakan sebuah disiplin tindakan karena menurut Swami Rama (2002) pengetahuan tertinggi adalah pengetahuan yang diperoleh dalam pengalaman langsung. Didalamnya kebenaran agama mendapat tempat yang paling mulia bagi kehidupan manusia.

\section{DAFTAR PUSTAKA}

Abdullah, Irwan. 2006. Konstruksi dan Reproduksi Kebudayaan. Yogyakarta : Pustaka Pelajar

Agung, Anak Agung Gde Putra. 2001. Perubahan Sosial dan Pertentangan Kasta di Bali Utara. Yogyakarta : Yayasan Untuk Indonesia.

Atmaja, Nengah Bawa. 2001. Reformasi Ke Arah Kemajuan Yang Sempurna dan Holistik Gagasan Perkumpulan Suryakanta tentang Bali di Masa Depan. Surabaya : Paramita.

Aziz, Abdul. 2006. Esai-esai Sosiologi Agama. Jakarta : Diva Pustaka.

Bagus, I Gusti Ngurah. 2004. Manusa dan Kebudayaan di Indonesia. Jakarta : Djambatan.

Barker, Chris. 2005. Culture Studies. Teori dan Praktis. Yogyakarta : Bentang.

Barth, Fredik. 1993. Balinese Words. Chicago \& London. The University of Chicago Press.

Dwipayana, AAGN Ari. 2001. Kelas Kasta. Pergulatan Kelas Menengah Bali. Yogyakarta : Lapera Pustaka Pustaka Utama. Kuasa.

2004. Bangsawan dan kembalinya Para Ningrat di dua Kota. Yogyakarta : Institude for Research and Empowerment.

Munandar, Agus Aris. 2009. Sejarah Kebudayaan Indonesia. Religi dan Falsafah, Jakarta : Raja Grafindo Persada.

Niel, Robert van. 2009. Munculnya Elite Modern Indonesia. Jakarta : Pustaka Jaya.

Nottingham, Elisabeth K. 1992. Agama dan Masyarakat. Jakarta : Rajawali Press.

O’Dea, Thomas F. 1985. Sosiologi Agama. Jakarta : CV. Rajawali. 
Outhwaite, Wiliam. Ed. 2008. Eksiklopedi Pemikiran Sosial Modern. Jakarta : Kencana Prenada Media Group.

Kerepun, Made Kembar. 2004. Benang Kusut Nama Gelar di Bali. Denpasar : CV. Bali Media Adhikarsa.

Ratna, Nyoman Kutha. 2005. Sastra dan Cultural Studies. Yogyakarta : Pustaka Pelajar.

Rey, Terry. 2007. Bourdieu on Religion. Imposing Faith and Legitimacy. London : Equinox.

Ritzer, George - Douglas J. Goodman. 2004. Teori Sosiologi Modern. Jakarta : Prenada Media.

Robinson, Geoffrey. 2006. Sisis Gelap Pulau Dewata. Sejarah Kekerasan Politik. Yogyakarta : LKIS.

Sanderson, Stephen K. 2003. Makro Sosiologi, Sebuah Pendekatan Terhadap Realitas Sosial. Jakarta PT. Raja Grafindo Persada.

Triguna, Ida Bagus Gde Yudha. 1986. "Munculnya Kelas Baru dan Dewangsanisasi. Transformasi dan Perubahan Sosial di Bali". Tesis. Yogyakarta : Fakultas Pasca Sarjana UGM.

Utama, I Wayan Budi. 2011. Adaptasi Budaya Masyarakat Bali Agama di Desa Cempaga Buleleng Dalam Merespon Regulasi Negara di Bidang Agama. Disertasi, tidak dipublikasikan. Denpasar: Program Doktor Kajian Budaya Universitas Udayana Denpasar. 